\title{
Hubungan Prokrastinasi Akademik Terhadap Prestasi Belajar Siswa Akuntansi Pada Masa Pandemi Covid-19
}

\author{
${ }^{*}$ Reny Sukmawati Yuhan"1), Muharam Yamleam²)
}

Program Studi Pendidikan Ekonomi, Fakultas Ilmu Pendidikan, Universitas Panca Sakti Bekasi

Corresepondence author: Renysukmwatiyuhan15@gmail.com

DOI: https://doi.org/10.37012/jipmht.v5i2.651

\begin{abstract}
ABSTRAK
Menunda menyelesaikan tugas atau Prokrasinasi akademik adalah salah satu masalah penting yang dihadapi siswa saat ini. Di masa pandemi seperti sekarang ini, keterlambatan penyelesaian pekerjaan rumah atau prokrastinasi akademik menjadi salah satu masalah penting yang dihadapi siswa-siswi dalam studinya, yang mengharuskan pemerintah menerapkan aturan Learning From Home (Belajar Dari Rumah). Ini bertujuan untuk menekan penyebaran virus Covid-19 yang telah menyebar dengan cepat di Indonesia sejak awal Maret 2020 yang terus mengalami peningkatan jumlah kasus positif di Indonesia. Prokrastinasi akademik adalah keterlambatan dalam memulai atau menyelesaikan tugas yang harus diselesaikan oleh siswa. Berdasarkan peristiwa tersebut, tujuan dari penelitian ini adalah untuk mengetahui apakah ada hubungan antara prokrastinasi akademik terhadap prestasi belajar siswa SMK Negeri 11 Kota Bekasi tahun ajaran 2020/2021. Dalam penelitian ini, penilis menggunakan metode penelitian yang bersifat kuantitatif korelatif yaitu mencari serta menetapkan adanya korelasi antara variabel - variabel penelitian. Pada penelitian ini variabel yang dimaksud yaitu prokrastinasi akademik dan prestasi belajar. Kuesioner skala Likert diujicobakan kepada 50 siswa sebagai subjek penelitian. Jumlah sampel penelitian merujuk pada tabel Isaac \& Michael dengan signifikansi 5\%. Dalam penelitian ini, penulis menggunakan SPSS 20 for windows dengan menerapkan uji validitas dan reliabilitas, uji normalitas, uji homogenitas, dan uji korelasi. Dalam penelitian ini, disimpulkan bahwa terdapat hubungan antara prokrastinasi akademik terhadap prestasi belajar siswa.
\end{abstract}

Kata kunci: Prokrastinasi Akademik, Prestasi Belajar Siswa, Pamdemi Covid-19

\begin{abstract}
Academic procrastination is one of the important problems facing students today. In the current pandemic, delays in completing homework or academic procrastination are one of the important problems faced by students in their studies, which requires the government to apply Learning From Home. This aims to suppress the spread of the Covid-19 virus which has spread rapidly in Indonesia. Academic procrastination is a delay in starting or completing assignments that must be completed by students. Based on this phenomenon, this study aims to determine the relationship between academic procrastination and student achievement at SMK Negeri 11 Kota Bekasi. The research uses a quantitative correlative research method, which is to find and determine the correlation between research variables. In this case the research variable in question is academic procrastination with academic achievement. Likert scale questionnaire was tested on 50 students as research subjects. The number of research samples refers to the table of Isaac \& Michael with a significance of 5\%. Data were analyzed using SPSS 20 for windows by applying validity and reliability tests, normality and homogeneity tests, and correlation tests. It was concluded that there was a relationship between academic procrastination and student achievement.
\end{abstract}




\section{PENDAHULUAN}

Para pendidik dan pelajar di banyak negara sangat merasakan dampak dari wabah virus corona yang pertama kali muncul di China. Pandemi ini sudah menyebar ke 156 negara, banyak sekolah harus tutup. ABC News melaporkan bahwa 22 negara di tiga benua menutup sekolah pada awal pandemi. Dalam laporannya, ABC News juga mencatat 13 negara telah meliburkan sekolah akibat pandemi ini. Di Indonesia, kegiatan belajar mengajar telah ditutup dalam upaya mengurangi penyebaran COVID19. Sedangkan sebagian proses belajar di rumah dengan materi dari sekolah dan dengan bantuan orang tua.

Belajar merupakan tugas utama siswa, namun tidak semua siswa memiliki manajemen waktu belajar yang baik. Manajemen waktu belajar yang kurang baik menyebabkan siswa menunda studinya. Penundaan telah menjadi salah satu topik yang paling banyak diteliti karena memiliki efek samping pada populasi umum dan siswa dalam ilmu-ilmu sosial. Kecenderungan umum untuk menunda tugas akademik telah dikonseptualisasikan sebagai penundaan akademik dalam pengaturan akademik. Prokrastinasi akademis yang didefinisikan oleh Rothblum, Solomon dan Murakami (1986), sebagai kecenderungan untuk menunda tugas akademis kemudian mengalami kecemasan yang terkait dengannya. Ini adalah masalah umum di kalangan siswa dan banyak siswa harus menghadapinya di hampir semua tahapan pendidikan, karena konsekuensi negatifnya seperti kegagalan akademik dan kesejahteraan yang lebih buruk.

Penundaan akademis mengacu pada kecenderungan untuk menunda pekerjaan sekolah secara sia-sia. Penundaan pekerjaan, dalam hal ini adalah mengerjakan tugas ataupun laporan terjadi pada siswa dari segala usia, baik siswa sekolah dasar ataupun mahasiswa di perguruan tinggi. Penundaan di antara mahasiswa sarjana di perguruan tinggi sangat umum dan beberapa penelitian bahkan menemukan bahwa lebih dari $70 \%$ mahasiswa mengakui bahwa mereka sering menunda-nunda (Schraw, Wadkins, \& Olafson, 2007). Penundaan seperti itu dapat menimbulkan kepanikan atau kecemasan yang seharusnya tidak terjadi pada saat mereka terburu-buru untuk memenuhi tenggat waktu dan menyelesaikan tugas. Melakukan penundaan tidak hanya dapat mepengaruhi kesehatan mental seseorang, namun dapat juga mepengaruhi interaksi atara pelaku dengan orang lain. Ketika individu gagal memenuhi tenggat waktu dan komitmen, hubungan menjadi tegang. Namun, penelitian agak beragam tentang efek penundaan. Misalnya, Schraw et al. (2007) berpendapat bahwa penundaan mungkin memiliki keuntungan adaptif yang berguna yang memungkinkan siswa untuk mendapatkan penggunaan waktu belajar yang lebih baik. 
Studi sebelumnya memperkirakan bahwa hampir 40-52 dari 100 siswa menunjukkan perilaku dilatory dalam pengaturan akademik (Solomon \& Rothblum, 1984; Özer, Demir, \& Ferrari, 2009). Sejumlah besar penelitian telah mengungkapkan bahwa penundaan akademik berdampak negatif terhadap kinerja akademik (misalnya Balkis, 2013; Kim \& Seo, 2015; Steel, 2007), course withdrawal (Rothblum et al. 1986), academic life satisfaction (Balkis, 2013; Chow, 2011), satisfaction with studies (Grunschel, Patrzek, \& Fries, 2013). Misalnya, dalam studi meta-analisis mereka, Kim dan Seo (2015) dan Steel (2007) menemukan bahwa penundaan berkorelasi negatif dengan kinerja akademik. Balkis (2013) menemukan bahwa siswa yang menunda-nunda melaporkan kepuasan akademik yang rendah. Keterbaruan dari penelitian ini dari penelitian-penelitian sebelumnya adalah yaitu karena penelitian ini dilakukan pada masa pandemi Berdasarkan latar belakang tersebut, penelitian ini bertujuan untuk mengetahui hubungan antara prokrastinasi akademik dengan prestasi belajar siswa akuntansi SMK Negeri 11 Kota Bekasi.

\section{METODE PENELITIAN}

Dalam penelitian ini peneliti menggunakan Metode Penelitian Korelasi Kuantitatif yaitu untuk mengetahui dan menentukan hubungan antar variabel penelitian. Dalam hal ini variabel penelitian yang dibahas adalah prokrastinasi akademik dan prestasi belajar. Hubungan antara dua variabel digambarkan dengan indikator statistik yang disebut koefisien korelasi. Koefisien menunjukkan sejauh mana perubahan satu variabel berhubungan dengan perubahan variabel lainnya. Sehingga peneliti dapat memahami keterkaitan antara penundaan akademik dengan prestasi akademik siswa SMK Negeri 11 Kota Bekasi.

1. Identifikasi Variabel

Dalam hubungan penelitian, variabel independen biasanya ditandai dengan simbol (X), dan variabel dependen biasanya ditandai dengan simbol (Y) (Azwar, 2003). Variabel yang akan diperiksa adalah:
a. Variabel Independen
: Prokrastinasi Akademik
b. Variabel Dependen
: Prestasi Belajar

2. Populasi dan Sampel

\section{a. Populasi}

Populasi menurut Arikunto adalah seluruh subjek penelitian. Populasi yang akan didukung oleh peneliti adalah siswa SMK Negeri 11 Kota Bekasi pada program studi akuntansi yang berjumlah 148 siswa. Sampel 
b. Sampel

Sampel Arikunto merupakan bagian dari populasi penelitian. Sampel yang digunakan dalam penelitian ini adalah 50 siswa.

c. Metode Pengumpulan Data

Data untuk penelitian ini akan dikumpulkan dari subjek penelitian dengan metode kuesioner. Disini peneliti menyebarkan kuesioner menggunakan google form sebagai alat pengumpulan data. Kuesioner skala likert diujikan pada 50 siswa.

\section{HASIL DAN PEMBAHASAN}

\section{Uji Validitas dan Reliabilitas Prokrastinasi akademik}

Setelah dilakukan pengecekan validitas pada soal prokrastinasi akademik dengan SPSS 20.0 pada 35 item, 30 item dinyatakan valid dan 5 item dinyatakan tidak valid/gagal. Elemen valid yang $r$ hitungnya lebih besar dari nilai pada table, $r$ adalah (0,279). Dari hasil perhitungan reliabilitas skala prokrastinasi akademik diperoleh nilai Alpha sebesar 0,904. Butir angket dikatakan reliabel jika nilai Alpha tiap butir lebih besar dari $r$ tabel $(0,279)$. Oleh karena itu, dari skor yang diperoleh keduanya dapat dikatakan memenuhi standar reliabilitas/keduanya dianggap reliabel dengan taraf signifikansi yang diambil sebesar 5\%.

\section{Tabel 1. Uji Reliabilitas}

\begin{tabular}{cc}
\hline \multicolumn{2}{c}{ Reliability Statistics } \\
\hline Cronbach's Alpha & N of Items \\
\hline 904 & 30
\end{tabular}

\section{Uji Normalitas dan Uji Homogenitas}

Uji prasyarat dalam penelitian ini menguji normalitas dan homogenitas data penelitian, berikut hasil uji prasyarat normalitas dengan melakukan uji One-Sample Kolmogorov-Smirnov Test didapat hasil sebagai berikut : 
Tabel 2. Uji Prasyarat Uji Normalitas Data

\begin{tabular}{l|l|r|r}
\multicolumn{2}{c}{ One-Sample Kolmogorov-Smirnov Test } \\
\hline \multicolumn{2}{c}{$\mathrm{N}$} & $\begin{array}{l}\text { Prokrastinsi } \\
\text { Akademik }\end{array}$ & $\begin{array}{c}\text { Prestasi } \\
\text { Belajar }\end{array}$ \\
\hline \multicolumn{2}{c}{ Normal Parameters } \\
\end{tabular}

Dari tabel diatas skor Asymp. Sig. (2-tailed) untuk variabel Prokrastinasi Belajar di dapat pvalue $=0.879>0,05$ dengan demikian variabel Prokrastinasi Akademik berdistribusi normal . Variabel Prestasi Belajar didapat p-value $=0.370>0.05$ dengan demikian variabel Prestasi Belajar berdistribusi normal.

Uji Homogenitas dalam penelitian ini dengan melakukan Levene's Test of Equality of Error Variances didapat hasil uji sebagai berikut :

\section{Tabel 3. Uji Homogenitas}

\section{Levene's Test of Equality of Error Variances ${ }^{a}$}

\begin{tabular}{cccc}
\multicolumn{2}{c}{ Dependent Variable: Skor } & & \\
\hline $\mathrm{F}$ & $\mathrm{df} 1$ & $\mathrm{df} 2$ & Sig. \\
\hline 1.306 & 1 & 98 & .072
\end{tabular}

Tests the null hypothesis that the error variance of the dependent variable is equal across groups.

a. Design: Intercept + Kelompok

Dari tabel diatas hasil uji levene menunjukan sig sebesar $0.072>0.05$ dengan demikian kedua kelompok data berasal dari kelmpok yang homogen.

1) Persamaan Linear dan Uji Signifikansi Koefisien Persamaan Regresi 
Tabel 4. Coefficients

Coefficients $^{\mathrm{a}}$

\begin{tabular}{|c|c|c|c|c|c|}
\hline \multirow[t]{2}{*}{ Model } & \multicolumn{2}{|c|}{$\begin{array}{l}\text { Unstandardized } \\
\text { Coefficients }\end{array}$} & \multirow{2}{*}{$\begin{array}{c}\text { Standardiz } \\
\text { ed } \\
\text { Coefficien } \\
\text { ts }\end{array}$} & \multirow[t]{2}{*}{$\mathrm{t}$} & \multirow[t]{2}{*}{$\begin{array}{l}\mathrm{Si} \\
\mathrm{g} .\end{array}$} \\
\hline & B & $\begin{array}{c}\text { Std. } \\
\text { Error }\end{array}$ & & & \\
\hline (Constant) & 88. & 1.536 & & 57. & .0 \\
\hline & 383 & & & 527 & $\begin{array}{l}0 \\
0 \\
\end{array}$ \\
\hline Prokrastin & - & .027 & -.393 & - & .0 \\
\hline si & .07 & & & 2.9 & 0 \\
\hline Akademik & 9 & & & 59 & 5 \\
\hline
\end{tabular}

a. Dependent Variable: Prestasi Belajar

Dari tabel di atas diperoleh konstanta $b_{0}=88.383$ dan koefisien regresi $b_{1}=-0.79$. Sehingga persamaan regresi linear adalah $\hat{\mathrm{Y}}=88.383+(-0.79) \mathrm{X}_{1}$.

Hipotesis: $\mathrm{H}_{0}: \beta_{1} \leq \mathrm{vs} \mathrm{H}_{1}: \beta_{1}>0$

Dari hasil analisis di atas menunjukan harga statistik untuk koefisien variabe $\mathrm{X}_{1}$ yaitu $\mathrm{t}_{\text {hit }}=$ 2.969 dan p-value $=0.005 / 2=0.0025<0.05$ (uji pihak kanan), atau $\mathrm{H}_{0}$ ditolak, yang bermakna prokrastinasi akademik berpengaruh terhadap prestasi belajar peserta didik.

2) Uji Signifansi Persamaan Regresi Ganda

\section{Tabel 5. Anova}

ANOVA $^{\mathrm{a}}$

\begin{tabular}{|c|c|c|c|c|c|c|}
\hline \multicolumn{2}{|c|}{ Model } & $\begin{array}{c}\text { Sum of } \\
\text { Squares }\end{array}$ & Df & $\begin{array}{c}\text { Mean } \\
\text { Square }\end{array}$ & $F$ & $\begin{array}{c}\text { Sig } \\
.\end{array}$ \\
\hline \multirow[t]{4}{*}{1} & Regres & 46.725 & 1 & 46.725 & 8.7 & .00 \\
\hline & sion & & & & 58 & $5^{b}$ \\
\hline & $\begin{array}{l}\text { Residu } \\
\text { al }\end{array}$ & 256.095 & 48 & 5.335 & & \\
\hline & Total & 302.820 & 49 & & & \\
\hline
\end{tabular}

a. Dependent Variable: Prestasi Belajar

b. Predictors: (Constant), Prokrastinsi Akademik

Hipotesis:

$\mathrm{H}_{0}: \beta_{1}=\beta_{2}$ atau $\mathrm{H}_{0}: \beta_{1}-\beta_{2}=0$

$\mathrm{H}_{0}: \beta_{1} \neq \beta_{2}$ atau $\mathrm{H}_{0}: \beta_{1}-\beta_{2}=0$

Dari hasil analisis yang disarikan pada tabel $\mathrm{ANOVA}^{\mathrm{b}}$ di atas diperoleh $\mathrm{F}_{\text {hit }}=8.758$, dan $\mathrm{p}$ value $=0.005<0.05$ atau hal ini berarti $\mathrm{H}_{0}$ ditolak. Artinya terdapat pengaruh linear variabel kemandirian prokrastinasi akademik dengan prestasi belajar peserta didik dimasa pandemi covid-19. Hal ini juga bermakna terdapat pengaruh secara bersama-sama (simultan) prokrastinasi akademik terhadap prestasi belajar dimasa pandemi covid-19. 


\section{Uji Hipotesis}

Uji hipotesis menggunakan metode analisis statistik Product Moment Karl Pearson denganrumus:

Hipotesis

Ho $=$ Tidak ada hubungan (korelasi) antara dua variabel

$\mathrm{Ha}=$ Ada hubungan (korelasi) antara dua variabel

\section{Tabel 6. Uji Korelasi}

\section{Correlations}

\begin{tabular}{|c|c|c|c|}
\hline & & $\begin{array}{c}\text { Prokrastinsi } \\
\text { Akademik }\end{array}$ & Prestasi Belajar \\
\hline Prokrastinsi & Pearson & 1 & $-.393^{* *}$ \\
\hline \multirow[t]{3}{*}{ Akademik } & Correlation & & \\
\hline & Sig. (2-tailed) & & .005 \\
\hline & $\mathrm{N}$ & 50 & 50 \\
\hline \multirow[t]{3}{*}{ Prestasi Belajar } & $\begin{array}{l}\text { Pearson } \\
\text { Correlation }\end{array}$ & $-.393^{* *}$ & 1 \\
\hline & Sig. (2-tailed) & .005 & \\
\hline & $\mathrm{N}$ & 50 & 50 \\
\hline
\end{tabular}

**. Correlation is significant at the 0.01 level (2-tailed).

Menurut data pada tabel di atas maka jenis hubungan antara variabel $\mathrm{Y}$ terhadap variabel $\mathrm{X}$ yaitu bersifat negatif, maksudnya ialah semakin tinggi Prokrastinasi akademik siswa maka Prestasi belajar siswa akan menurun, sebaliknya jika tingkat prokrastinasi atau sifat menunda nunda pekerjaan dalam belajar rendah maka semakin tinggi juga prestasi belajar siswa.

Menurut data pada tabel di atas juga dapat disimpulkan bahwa ada korelasi antara variabel prokrastinasi akademik dengan variabel prestasi belajar yaitu dengan nilai signifikansi 0,005 < 0,05. Dan tingkat keeratan hubungan pada data diatas dengan menggunakan kriteria Guilford (1956) yaitu sebesar (- 0,393) termasuk dalam kategori Hubungan rendah tapi pasti. Hasil uji korelasi diperoleh berdasarkan ketentuan $\mathrm{r}$ hitung lebih besar dari $\mathrm{r}$ tabel, maka Ha diterima dan Ho ditolak yaitu $(0,393>0,279)$.

Berdasarkan hail uji deskriptif dapat disimpulkan bahwa prokrastinasi akademik pada siswa SMK Negeri 11 Kota Bekasi termasuk dalam kategori rendah ditandai dengan sebanyak 42 siswa atau sekitar $84 \%$ berada di kategori rendah. Hal ini menunjukkan bahwa tidak semua siswa tersebut melakukan perilaku prokrastinasi dalam pembelajaran. Namun demikian ada sejumlah siswa yang memiliki tingkat prokrastinasi tinggi, yaitu sebanyak 8 siswa atau sekitar $16 \%$. 


\section{SIMPULAN}

Berdasarkan hasil penelitian ini dapat disimpulkan bahwa terdapat hubungan yang signifikan antara kelambatan akademik dengan prestasi belajar siswa di SMK Negeri 11 Kota Bekasi Tahun Pelajaran 2019/2020. Berdasarkan hasil penelitian di atas, maka peneliti menyarankan beberapa hal, yaitu:

1. Diharapkan siswa tidak melakukan dan menerapkan perilaku prokrastinasi dalam proses pembelajaran maupun dalam hal mengerjakan tugas. Yaitu dengan tidak menunda-nunda suatu pekerjaan dalam mengerjakan tugas.

2. Perilaku prokrastinasi diharapkan tidak terus-menerus menjadi kebiasaan siswa dalam setiap pembelajaran.

3. Bagi guru, berdasarkan penelitian diketahui perilaku prokrastinasi atau menunda-nunda pekerjaan terhadap prestasi belajar siswa dikategorikan rendah, diharapkan setiap guru mata pelajaran ataupun wali kelas dapat lebih memperhatikan perilaku atau tingkah laku siswanya, agar dapat mencegah siswa-siswa tersebut melakukan tindakan prokrastinasi dalam setiap pembelajaran

\section{REFERENSI}

Candra, Ujang, Mungin Eddy Wibowo, and Ninik Setyowani. 2014. "Indonesian Journal of Guidance and Counseling: Theory and Application.” 3(3):66-72.

Fauziah, Hana Hanifah. n.d. "Fakor-Faktor Yang Mempengaruhi Prokrastinasi Akademik Pada Mahasiswa Fakultas Psikologi Uin Sunan Gunung Djati Bandung.” (105).

Jurnal, Kognisi. 2017. "MAHASISWA FAKULTAS PSIKOLOGI UNIVERSITAS POTENSI UTAMA Zuraida Fakultas Psikologi Universitas Potensi Utama Jalan K . L . Yos Sudarso Km .6 . 5 No . 3 A Tanjung Mulia Medan Abstrak.” 2(1):30-41.

Mccloskey, Justin, and Shannon A. Scielzo. n.d. "Finally!: The Development and Validation of the Academic Procrastination Scale."

Supriyadi, Supriyadi. 2020. "Pengaruh Kemandirian Dan Dukungan Orangtua Pada Pembelajaran Jarak Jauh Terhadap Prestasi Belajar Dimasa Pandemi Covid-19.” Jurnal Inovasi Pendidikan MH Thamrin 4(2):56-69. doi: 10.37012/jipmht.v4i2.434. 